\title{
Response of artificially defoliated Betula pendula seedlings to additional soil nutrient supply
}

\author{
Valda Araminiene, \\ Iveta Varnagiryte-Kabašinskiene, \\ Vidas Stakenas
}

\begin{abstract}
The impact of leaf damage on the growth of young silver birch seedlings with and without additional nutrient supply was investigated by simulating leafinsect damage and applying different levels $(25 \%, 50 \%$ and $75 \%)$ of artificial defoliation. Based on field-practical and cost-effective methods, we determined how fertilization practices compensate for foliage loss, and the combined effect on silver birch seedling growth. The mineral fertilizers applied to the 25-75\%-defoliated silver birch seedlings reduced the growth in aboveground biomass compared to the fertilized but undamaged seedlings. Our results showed that when the birch seedlings received more nutrients they did not compensate for the loss of foliar mass. However, the seedlings loosing part of their foliar mass and receiving no additional fertilizers did compensate for the foliage loss and their root growth was not weakened, using soil nutrients more effectively. Mineral fertilization up to optimal nutritional balance could be a beneficial tool for increasing growth rate and biomass accumulation in the short-term period. However, our study demonstrated that additional fertilization does not necessarily lead to growth compensation of partly defoliated young birch trees.
\end{abstract}

Keywords: Betula pendula, Artificial Defoliation, Fertilization, Aboveground Biomass, Photosynthesis
Plant response to herbivores is affected by various environmental factors, including the soil nutrient status. Mutikainen et al. (2000) reviewed the carbon-nutrient balance hypothesis, which explains the variation of herbivore-induced resistance in terms of different soil fertility and light regimes. Defoliation can affect the carbonnutrient balance of plants by removing more nutrients than carbon, as observed both at the ecosystem level (Finér 1992, Nilsen \& Abrahamsen 2003, Hytönen et al. 2014) and under a controlled environment (Huttunen et al. 2007, 2013, Kula et al. 2012, Varnagiryte-Kabašinskiene et al. 2015). Moreover, it has been suggested that fertilization is required for more intensive mineralization rates of organic nitrogen in soil under climate warming or increased $\mathrm{N}$ depositions (Mäkipää et al. 1999, Galloway et al. 2004, Verburg 2005).

The capacity of trees to allocate elements $\square$ Institute of Forestry, Lithuanian Research Centre for Agriculture and Forestry, Liepu str. 1, Girionys, LT-53101, Kaunas district (Lithuania)

@ Iveta Varnagiryte-Kabašinskiene (iveta.kabasinskiene@mi.lt)

Received: Apr 12, 2016 - First Accepted: Jul 02, 2016 - Final Acceptance: Nov 13, 2016

Citation: Araminiene V, Varnagiryte-Kabašinskiene I, Stakenas V (2017). Response of artificially defoliated Betula pendula seedlings to additional soil nutrient supply. iForest 10: 281-287. - doi: 10.3832/ifor2086-009 [online 2016-12-13]

Communicated by: Gianfranco Minotta within their tissues has been widely discussed (Finér 1992, Brække \& Håland 1995, Thelin 2000). Huttunen et al. (2012) observed that defoliation might weaken the ability of roots to store resources, which is caused by changes in carbon allocation to aboveground tissues. Previous studies indicated that the ability of defoliated silver birch seedlings to recover from and compensate for the loss of leaf biomass was improved by fertilization (Mutikainen et al. 2000, Eyles et al. 2009). For example, fertilization has increased the height increment and biomass growth of defoliated silver birch seedlings (Huttunen et al. 2007). As an opposite interaction, intensive photosynthesis and growth caused by defoliation may induce soil nutrient disproportions (Zhang et al. 2006, Turnbull et al. 2007).

The capability of birch species to exhibit compensatory growth and recover after severe defoliation was found to improve after increasing the nutrient supply (Reich et al. 1993, Mutikainen et al. 2000). Furthermore, it was reported that nutrient availability may affect how the total biomass responded to defoliation; however, no interaction between defoliation and fertilization was found in the second growing season after defoliation (Anttonen et al. 2002).

The study by Eyles et al. (2009) examined the interactive effects of belowground resource limitations by varying nutrient and water availability, and aboveground carbon limitation imposed by a single $40 \%$ defoliation on stem growth, below- and above- 
ground biomass allocation patterns in 8month-old, field-grown Eucalyptus globulus Labill. saplings. This study assumed that in the short term the trees grown with adequate water and nutrient supplies, and those grown with low-nutrient supply, were able to compensate for the foliage loss. However, the effect of defoliation on biomass and resource allocation patterns had not been fully realized after five months of recovery time (Eyles et al. 2009).

Contrary to the widely discussed compensatory continuum hypothesis, which predicts lower tolerance under low soil nutrient supply (Maschinski \& Whitham 1989), several studies have demonstrated that trees are less tolerant to defoliation under high rather than low soil nutrient supply (Hawkes \& Sullivan 2001, Wise \& Abrahamson 2005). The tolerance is also related to other environmental factors, such as damage frequency and severity (Houle \& Simard 1996, Wise \& Abrahamson 2005, Pinkard et al. 2007). Stevens et al. (2008) reported a positive correlation of aspen tolerance with the proportion of biomass in stems under low-nutrient conditions and no defoliation event; however, it was correlated with greater allocation to stems under high-nutrient conditions and defoliation event.

Erbilgin et al. (2014) focused on the compensatory growth of trembling aspen seedlings under varying defoliations, with or without nutrient-enriched substrate, suggesting interactions between frequency and intensity of defoliation and nutrient availability. According to Erbilgin et al. (2014), lower defoliation induced biomass accumulation of defoliated seedlings, regardless of nutrient availability. Otherwise, under higher defoliation, compensatory growth varied depending on nutrient availability.

This paper attempts to analyze the impact of simulated leaf damage, which was chosen to demonstrate leaf-insect damage and artificial defoliation up to $75 \%$ on the growth of young silver birch seedlings with and without additional nutrient (N, P, K and $\mathrm{Mg}$ ) supply. We hypothesized that mechanical defoliation is an appropriate method for the compensatory growth studies of trees (Boege 2005) and that the type of insect damage, such as leaf-chewing or leaf perforation, is more important than how this damage was conducted (Massad 2013). Although silver birch grows on a wide range of soil conditions (Vanhellemont et al. 2016), the increase of final silver birch biomass could be improved by soil nutrient supply. In parallel, this could prevent foliar biomass loss caused by insects. If soil fertilization leads to a positive outcome, the following technique could be applied in the field when birch plantations are planned or managed.

\section{Material and methods}

\section{Field experiment}

Throughout the vegetation season of 2015, silver birch (Betula pendula Roth) seedlings that originated from central $\mathrm{Li}$ thuania ( $54^{\circ} 51^{\prime} \mathrm{N}, 24^{\circ} 03^{\prime} \mathrm{E}$ ) were grown at the Dubrava Experimental and Training Forest Enterprise. One-year-old silver birch seedlings were planted into individual $4-\mathrm{L}$ plastic pots filled with a mixed substrate (mixture of sand and neutralized peat in a ratio 1:5, respectively) at the beginning of April 2015. The mean height of selected birch seedlings was $45.7 \pm 0.2 \mathrm{~cm}$ and mean diameter at $2 \mathrm{~cm}$ above ground level was $4.17 \pm 0.04 \mathrm{~mm}$, normally developed, with no visual damage. All seedlings were irrigated as needed throughout the summer. Pots had perforations in the base to allow excess water to drain.

The seedlings were randomly assigned into fertilized, which received $120 \mathrm{~kg} \mathrm{ha}^{-1}$ nitrogen, $90 \mathrm{~kg} \mathrm{ha}^{-1}$ phosphorus, $135 \mathrm{~kg} \mathrm{ha}^{-1}$ potassium and $35 \mathrm{~kg}^{-1}$ magnesium, and unfertilized seedlings. The applied amount of NPKMg fertilizers corresponded to the optimal amount of fertilizers commonly used for one-year-old birch seedlings. The optimal fertilizer dosage for the particular substrate was experimentally defined at the Agrochemical laboratory of Lithuanian Research Center for Agriculture and Forestry. Granulated NPK fertilizer was mixed to substrate as raw material, leaving it to dissolve gradually during the vegetation season, while $\mathrm{Mg}$ fertilizer was dissolved in water. All fertilizers were applied once over a period of six-week after planting of birch seedlings.

In the middle of June 2015, fertilized and unfertilized seedlings were allocated to 25 , 50 and $75 \%$ artificial defoliation, and three treatments simulating insect damage (three or six holes per leaf, or clipping onethird off each leaf) were conducted. The defoliation was conducted using scissors, each leaf was damaged with three or six non-overlapping holes $\left(0.33 \mathrm{~cm}^{2}\right)$ using a steel hole-punch, or one-third of each leaf was removed using scissors. Defoliation treatments were applied once. In total, seven treatments were conducted, including a non-defoliated control. No visible injury caused by biotic or abiotic agents was observed during the experimental period. Each treatment had 10 replicates, a total of 140 seedlings were grown during the experiment.

The potted trees were placed adjacent to each other in rows mixing the treatments, covering an experimental area of $130 \times 360$ $\mathrm{cm}$. The artificial defoliation was designed to approximate the actual levels of insect defoliation during the active vegetation period in Lithuania. The mean temperature of the 2015 growing season in the study area was $14.4^{\circ} \mathrm{C}$, ranging from $7.3^{\circ} \mathrm{C}$ in April to $20.1{ }^{\circ} \mathrm{C}$ in August (data from the meteorological station situated $0.5 \mathrm{~km}$ away from the study area). The mean precipitation was $23.8 \mathrm{~mm}$, with $43.2 \mathrm{~mm}$ in April, 42.0 $\mathrm{mm}$ in May, $10.0 \mathrm{~mm}$ in June, $21.2 \mathrm{~mm}$ in July and $2.6 \mathrm{~mm}$ in August. These meteorological values were close to the standard climatic norm.

\section{Measurements}

The height of birch seedlings was measured periodically 1,5 and 10 weeks postdefoliation on June 29, July 30 and August 30 , respectively.

The net photosynthetic rate of the remnant leaves was measured two weeks postdefoliation (July 10) with a portable photosynthetic system LCpro-SD ${ }^{\circledast}$ (ADC BioScientific Ltd, England). The measurements were conducted between 10:00 $A M$ and 12:00 PM, having similar environmental conditions for all samples. Three seedlings were systematically selected and measured from all fertilized and unfertilized treatments. The photosynthetic rate was measured for three leaves from each seedling, yielding nine leaves per treatment. We measured mature, sunlit, naturally undamaged leaves in each treatment.

The diameter of the main stem of each individual seedling was measured at a distance of $2 \mathrm{~cm}$ above the stump base using an electronic digital caliper before final harvesting.

The above- and belowground biomass of seedlings was estimated at the end of the experiment, i.e., on September 02, or approximately 10 weeks post-defoliation. For the determination of total dry mass, samples were removed from the following tree compartments: leaves, living and dead shoots, branches, stems and roots. Roots were rinsed free of soil and oven-dried to determine the total belowground biomass. The samples were transported to the laboratory in paper bags and stored in a ventilated room. The oven drying took place in the weeks immediately after sampling. The removed biomass from each treatment, as well as the final live biomass, was collected and oven-dried to a constant weight at 60 ${ }^{\circ} \mathrm{C}$ to determine the accumulated aboveground biomass.

\section{Calculations and statistical analysis}

The total aboveground biomass of each tree was calculated by summing the masses of dried shoots, branches and leaves. The total biomass of each seedling was calculated by summing the above- and belowground biomasses. Leaf, aboveground, and cumulative dry mass were calculated by summing the dry mass at harvest plus the leaf mass removed during defoliation. Root biomass was expressed in relation to the aboveground biomass, and the root-to-shoot ratio was calculated. Cumulative leaf dry mass in relation to the root was calculated, and the ratio of leaf production-to-root ratio was obtained.

Growth compensation of seedlings (i.e., whether they partially or fully compensated for the removal of leaf biomass) was assessed by comparing the height incre- 
ment, photosynthetic rate and final biomass of defoliated seedlings with the same variables measured in the control seedlings both during the growing period and at final harvest.

Normal distribution of the above variables was tested using the non-parametric Lilliefors and Kolmogorov-Smirnov tests. Due to non-normal distribution of data, we used the Kruskal-Wallis analysis of variance (KW-ANOVA) test to ascertain the significance of differences in dry mass between treatments. Treatment means are presented throughout the study with the standard error of the mean $( \pm \mathrm{SE})$.

All statistical analyses were conducted using the software package STATISTICA ${ }^{\circledR}$ ver. 7.0 (StatSoft Inc., Tulsa, OK, USA) with $a=0.05$ in all cases.

\section{Results}

Effect on height and stem growth

To compare the growth of fertilized and unfertilized one-year-old silver birch seedlings, the height increment was measured just before harvesting. The increment in height of fertilized seedlings was 1.5 times higher than that of unfertilized seedlings, decreasing from $32.1 \pm 1.2$ (the control) by $20-23 \%$ (25-50\% defoliation). In the case of fertilized birch trees, $25-75 \%$ defoliated seedlings reached a lower height increment compared with the fertilized control (Fig. 1). These results suggest a slight height decrease with more severe damage. Similar tendencies were recorded for the stem increment. The fertilization increased stem growth by 3-4 times compared to unfertilized seedlings (Fig. 2). In the case of unfertilized seedlings, both artificial insect damage (three, six holes and clipped onethird leaf, which correspond to 10, 20 and $27 \%$ defoliation, respectively) and all defoliation treatments $(25,50$ and $75 \%)$ did not significantly influence the stem growth at harvest. However, in the case of fertilized trees, defoliation of about $25 \%$ significantly increased stem growth by $20-35 \%$ compared to fertilized control.

\section{Effect on leaf photosynthesis intensity}

Photosynthesis intensity of unfertilized seedlings varied depending on the damage intensity, with a tendency to increase with increasing defoliation (Fig. 3). Three weeks post-treatment, the photosynthetic rate of unfertilized seedlings was 7.8 times higher in the $75 \%$ defoliated unfertilized seedlings compared to non-defoliated unfertilized control. However, no significant impact of defoliation on photosynthesis intensity was found in the fertilized seedlings.

\section{Effect on final above- and belowground biomass}

At harvest, differences between the total production of fertilized and unfertilized seedlings were the most significant (Tab. 1). According to the treatment intensity, total productivity of fertilized seedlings

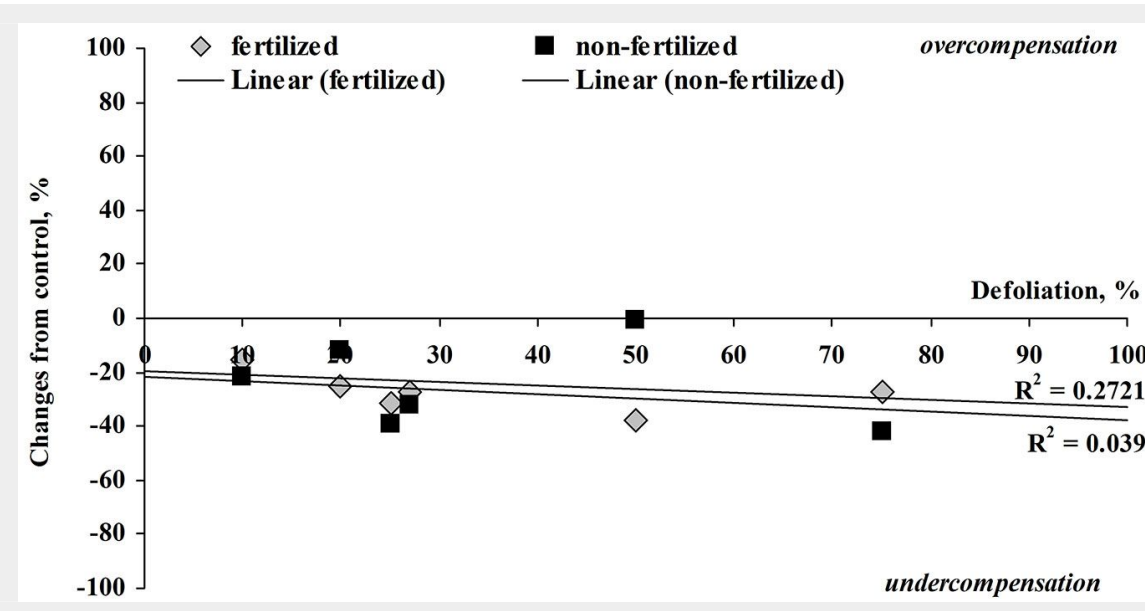

Fig. 1 - Relationship between the percentage change in height from control ( $0 \%$ is equal to control) and defoliation (\%) in fertilized and not fertilized silver birch seedlings at harvest.

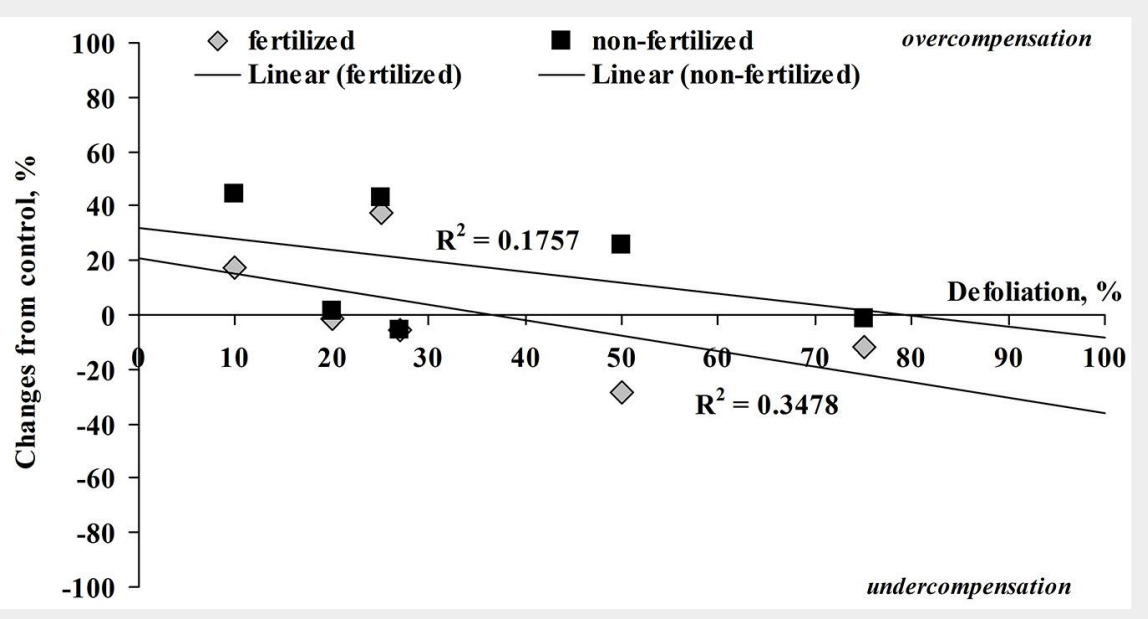

Fig. 2 - Relationship between the percentage change in stem diameter from control ( $0 \%$ is equal to control) and defoliation (\%) in fertilized and non-fertilized silver birch seedlings at harvest.

was 2.1 ( $50 \%$ defoliation) to 4.9 (control) $6.72 \pm 0.66 \mathrm{~g}$ (50\% defoliation). In the case times higher than the final productivity of of unfertilized seedlings, no significant difunfertilized seedlings. Total productivity of ferences between the treatments (all defounfertilized seedlings varied in a narrow liation levels) were recorded. All unfertilrange from $5.55 \pm 0.51$ ( $75 \%$ defoliation) to ized seedlings grew at a similar intensity,

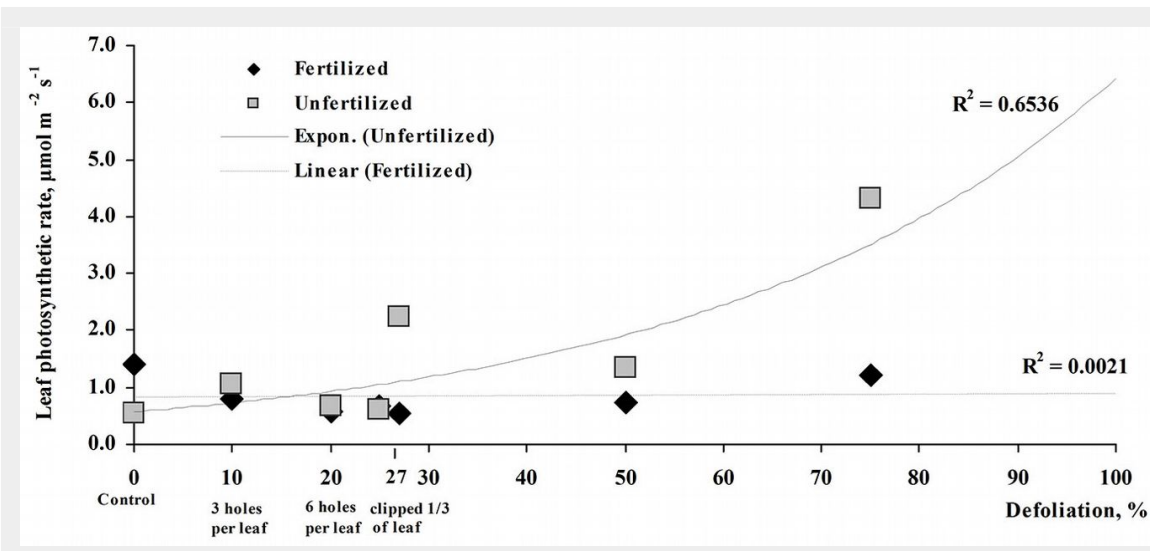

Fig. 3 - Leaf photosynthetic rate $\left(\mu \mathrm{mol} \mathrm{m} \mathrm{m}^{-2}\right)$ of fertilized and unfertilized silver birch seedlings at increasing defoliation percentage. 
Tab. 1 - Dry mass (g) of leaves, shoots, stems and roots of fertilized and non-fertilized B. pendula seedlings at harvest. Values are means \pm SE $(n=10)$. Different letters within a row indicate significant differences in dry mass between treatments after Kruskal-Wallis ANOVA ( $p<0.05)$. (1): Leaf production include leaf lost in defoliation (cumulative dry mass); (2): Total production by summing the dry mass at harvest plus the leaf mass removed in defoliation events; (3): Gram roots / (gram stems + gram shoots + gram leaf).

\begin{tabular}{|c|c|c|c|c|c|c|c|c|}
\hline \multirow{2}{*}{ Variable } & \multirow{2}{*}{$\begin{array}{l}\text { Ferti- } \\
\text { lizers }\end{array}$} & \multirow{2}{*}{ Control } & \multicolumn{3}{|c|}{$\begin{array}{c}\text { Artificial defoliation / } \\
\text { simulated insect damage }\end{array}$} & \multicolumn{3}{|c|}{ Artificial defoliation } \\
\hline & & & $\begin{array}{l}10 \% \text { / } 3 \text { holes } \\
\text { per leaf }\end{array}$ & $\begin{array}{l}20 \% \text { / } 6 \text { holes } \\
\text { per leaf }\end{array}$ & $\begin{array}{l}27 \% \text { / clipped } \\
1 / 3 \text { of leaf }\end{array}$ & $25 \%$ & $50 \%$ & $75 \%$ \\
\hline \multirow[t]{2}{*}{ Leaf mass ( $\mathrm{g}$ ) } & Yes & $6.03 \pm 0.54^{c}$ & $4.57 \pm 0.50^{b c}$ & $3.29 \pm 0.36^{\mathrm{abc}}$ & $3.77 \pm 0.41^{\mathrm{abc}}$ & c $3.79 \pm 0.61^{\mathrm{abc}}$ & $2.41 \pm 0.32^{\mathrm{ab}}$ & $2.26 \pm 0.23^{\mathrm{ab}}$ \\
\hline & No & $0.85 \pm 0.32^{a b}$ & $1.06 \pm 0.18^{b}$ & $0.62 \pm 0.06^{a b}$ & $0.86 \pm 0.09 a b$ & $0.71 \pm 0.08^{a b}$ & $0.75 \pm 0.13^{a b}$ & $0.48 \pm 0.12^{a}$ \\
\hline \multirow[t]{2}{*}{ Leaf production $(\mathrm{g})^{1}$} & Yes & $6.03 \pm 0.54^{b}$ & $4.91 \pm 0.50^{a b}$ & $3.92 \pm 0.36^{a b}$ & $4.38 \pm 0.41^{a b}$ & $4.44 \pm 0.61^{a b}$ & $3.63 \pm 0.32^{a}$ & $3.51 \pm 0.23^{a}$ \\
\hline & No & $0.85 \pm 0.32^{b}$ & $1.19 \pm 0.18^{a b}$ & $0.83 \pm 0.06^{\mathrm{ab}}$ & $1.03 \pm 0.09^{a b}$ & $0.81 \pm 0.08^{a b}$ & $1.28 \pm 0.13^{\mathrm{ab}}$ & $1.26 \pm 0.12^{a}$ \\
\hline \multirow[t]{2}{*}{ Shoot mass (g) } & Yes & $2.18 \pm 0.27^{b}$ & $1.26 \pm 0.19^{a b}$ & $0.85 \pm 0.10^{a}$ & $1.02 \pm 0.14^{a b}$ & $0.89 \pm 0.13^{a}$ & $0.77 \pm 0.14^{a}$ & $0.93 \pm 0.13^{\mathrm{a}}$ \\
\hline & No & $0.11 \pm 0.04^{a}$ & $0.16 \pm 0.03^{a}$ & $0.11 \pm 0.01^{a}$ & $0.13 \pm 0.02^{a}$ & $0.09 \pm 0.04^{a}$ & $0.15 \pm 0.06^{a}$ & $0.10 \pm 0.02^{\mathrm{a}}$ \\
\hline \multirow[t]{2}{*}{ Stem mass (g) } & Yes & $8.91 \pm 0.54^{b}$ & $7.10 \pm 0.69^{\mathrm{ab}}$ & $5.80 \pm 0.61^{\mathrm{ab}}$ & $5.98 \pm 0.52^{\mathrm{ab}}$ & $5.95 \pm 0.70^{\mathrm{ab}}$ & $4.68 \pm 0.38^{a}$ & $5.44 \pm 0.46^{\mathrm{a}}$ \\
\hline & No & $2.43 \pm 0.36^{a}$ & $2.59 \pm 0.18^{a}$ & $2.29 \pm 0.17^{a}$ & $2.47 \pm 0.15^{a}$ & $2.71 \pm 0.21^{\mathrm{a}}$ & $2.58 \pm 0.20^{a}$ & $2.18 \pm 0.12^{\mathrm{a}}$ \\
\hline \multirow[t]{2}{*}{ Aboveground mass (g) } & Yes & $17.13 \pm 1.31^{b}$ & $12.93 \pm 1.33^{a b}$ & $9.95 \pm 1.04^{a}$ & $10.77 \pm 0.98^{a b}$ & $10.63 \pm 1.42^{a b}$ & $7.85 \pm 0.75^{\mathrm{a}}$ & $8.63 \pm 0.80^{\mathrm{a}}$ \\
\hline & No & $3.39 \pm 0.72^{a}$ & $3.79 \pm 0.34^{\mathrm{a}}$ & $3.01 \pm 0.22^{a}$ & $3.46 \pm 0.26^{a}$ & $3.51 \pm 0.28^{a}$ & $3.48 \pm 0.36^{a}$ & $2.76 \pm 0.23^{\mathrm{a}}$ \\
\hline \multirow{2}{*}{$\begin{array}{l}\text { Aboveground } \\
\text { production (g) }\end{array}$} & Yes & $17.13 \pm 1.31^{b}$ & $13.28 \pm 1.33^{a b}$ & $10.57 \pm 1.04^{\mathrm{ab}}$ & $11.38 \pm 0.98 \mathrm{ab}$ & $11.28 \pm 1.42^{a b}$ & $9.07 \pm 0.75^{a}$ & $9.88 \pm 0.80^{a}$ \\
\hline & No & $3.39 \pm 0.72^{a}$ & $3.39 \pm 0.34^{a}$ & $3.22 \pm 0.22^{\mathrm{a}}$ & $3.63 \pm 0.26^{a}$ & $3.61 \pm 0.28^{a}$ & $4.01 \pm 0.36^{a}$ & $3.54 \pm 0.23^{a}$ \\
\hline \multirow[t]{2}{*}{ Root mass (g) } & Yes & $10.34 \pm 0.72^{b}$ & $7.84 \pm 0.74^{\mathrm{ab}}$ & $6.11 \pm 0.72^{\mathrm{a}}$ & $6.99 \pm 0.53^{a b}$ & $6.54 \pm 0.74^{a b}$ & $4.87 \pm 0.46^{\mathrm{a}}$ & $5.31 \pm 0.50^{\mathrm{a}}$ \\
\hline & No & $2.23 \pm 0.42^{a}$ & $2.75 \pm 0.24^{a}$ & $2.19 \pm 0.17^{a}$ & $2.41 \pm 0.24^{a}$ & $2.69 \pm 0.27^{a}$ & $2.71 \pm 0.31^{\mathrm{a}}$ & $2.01 \pm 0.30^{\mathrm{a}}$ \\
\hline \multirow[t]{2}{*}{ Total mass (g) } & Yes & $27.47 \pm 2.02^{b}$ & $20.77 \pm 2.06^{\mathrm{ab}}$ & $16.05 \pm 1.73^{a}$ & $17.76 \pm 1.48^{a b}$ & $17.18 \pm 2.07^{a b}$ & $12.73 \pm 1.18^{a}$ & $13.94 \pm 1.28^{a}$ \\
\hline & No & $5.62 \pm 1.12^{\mathrm{a}}$ & $6.54 \pm 0.57^{a}$ & $4.96 \pm 0.29^{a}$ & $5.87 \pm 0.48^{\mathrm{a}}$ & $6.20 \pm 0.53^{a}$ & $6.19 \pm 0.66^{a}$ & $4.77 \pm 0.51^{\mathrm{a}}$ \\
\hline \multirow[t]{2}{*}{ Total production $(\mathrm{g})^{2}$} & Yes & $27.47 \pm 2.02^{b}$ & $21.11 \pm 2.06^{\mathrm{ab}}$ & $16.68 \pm 1.73^{a}$ & $18.37 \pm 1.48^{\mathrm{ab}}$ & $17.83 \pm 2.07^{\mathrm{ab}}$ & $13.95 \pm 1.18^{a}$ & $15.19 \pm 1.28^{a}$ \\
\hline & No & $5.62 \pm 1.12^{a}$ & $6.67 \pm 0.57^{a}$ & $5.17 \pm 0.29^{a}$ & $6.04 \pm 0.48^{a}$ & $6.30 \pm 0.53^{a}$ & $6.72 \pm 0.66^{\mathrm{a}}$ & $5.55 \pm 0.51^{\mathrm{a}}$ \\
\hline \multirow[t]{2}{*}{ Root/shoot ratio ${ }^{3}$} & Yes & $0.61 \pm 0.02^{a}$ & $0.60 \pm 0.02^{a}$ & $0.57 \pm 0.04^{a}$ & $0.62 \pm 0.02^{a}$ & $0.59 \pm 0.03^{a}$ & $0.54 \pm 0.02^{a}$ & $0.53 \pm 0.02^{\mathrm{a}}$ \\
\hline & No & $0.67 \pm 0.05^{\mathrm{a}}$ & $0.70 \pm 0.02^{\mathrm{a}}$ & $0.64 \pm 0.09^{\mathrm{a}}$ & $0.66 \pm 0.03^{\mathrm{a}}$ & $0.74 \pm 0.04^{\mathrm{a}}$ & $0.67 \pm 0.04^{a}$ & $0.56 \pm 0.04^{\mathrm{a}}$ \\
\hline
\end{tabular}

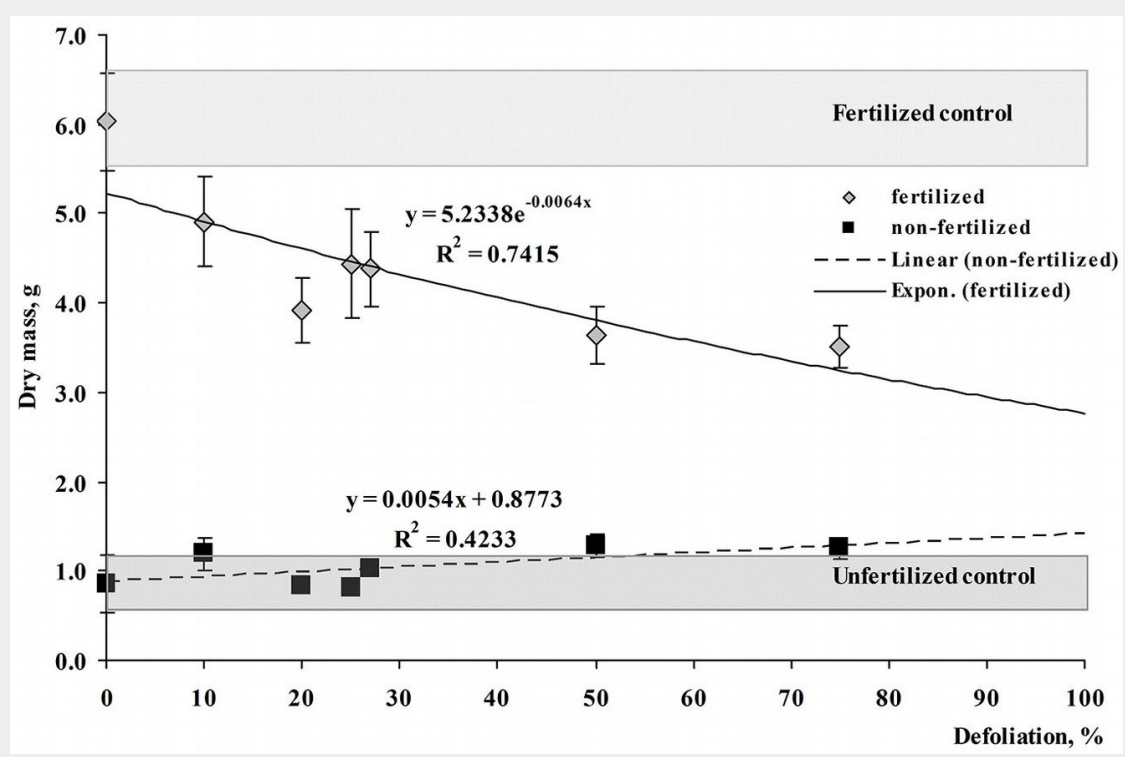

Fig. 4 - Relationship between dry leaf mass (g) and defoliation (\%) in fertilized and nonfertilized silver birch seedlings at harvest. Grey boxes represent the range of dry leaf mass values observed for control seedlings.

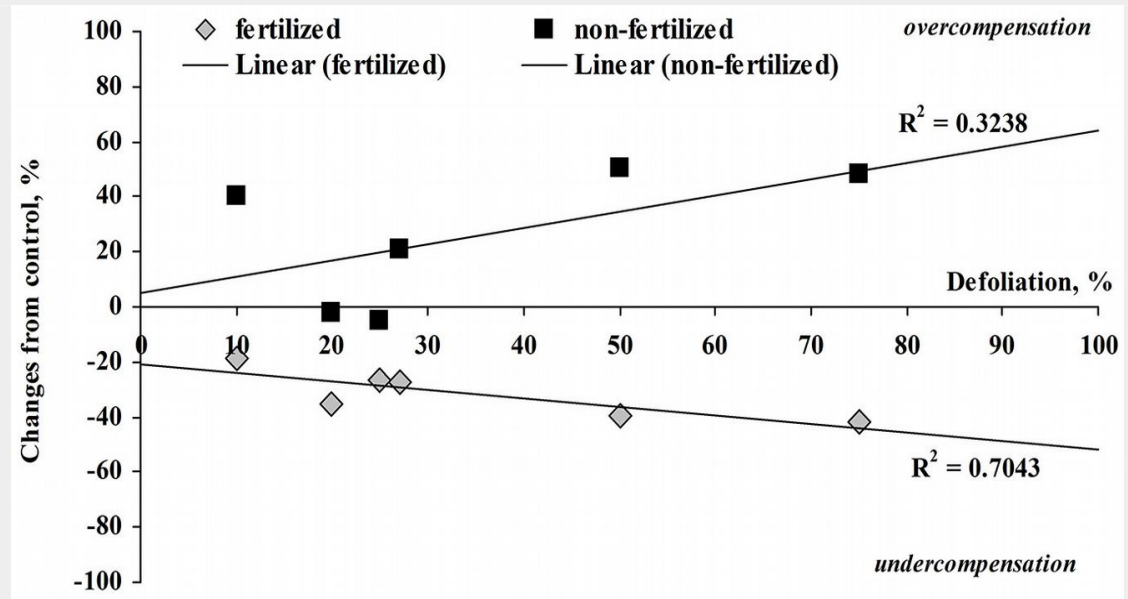

Fig. 5 - Relationship between the percentage change in leaf production from control $(0 \%$ is equal to control) and defoliation (\%) in fertilized and non-fertilized silver birch seedlings at harvest. 


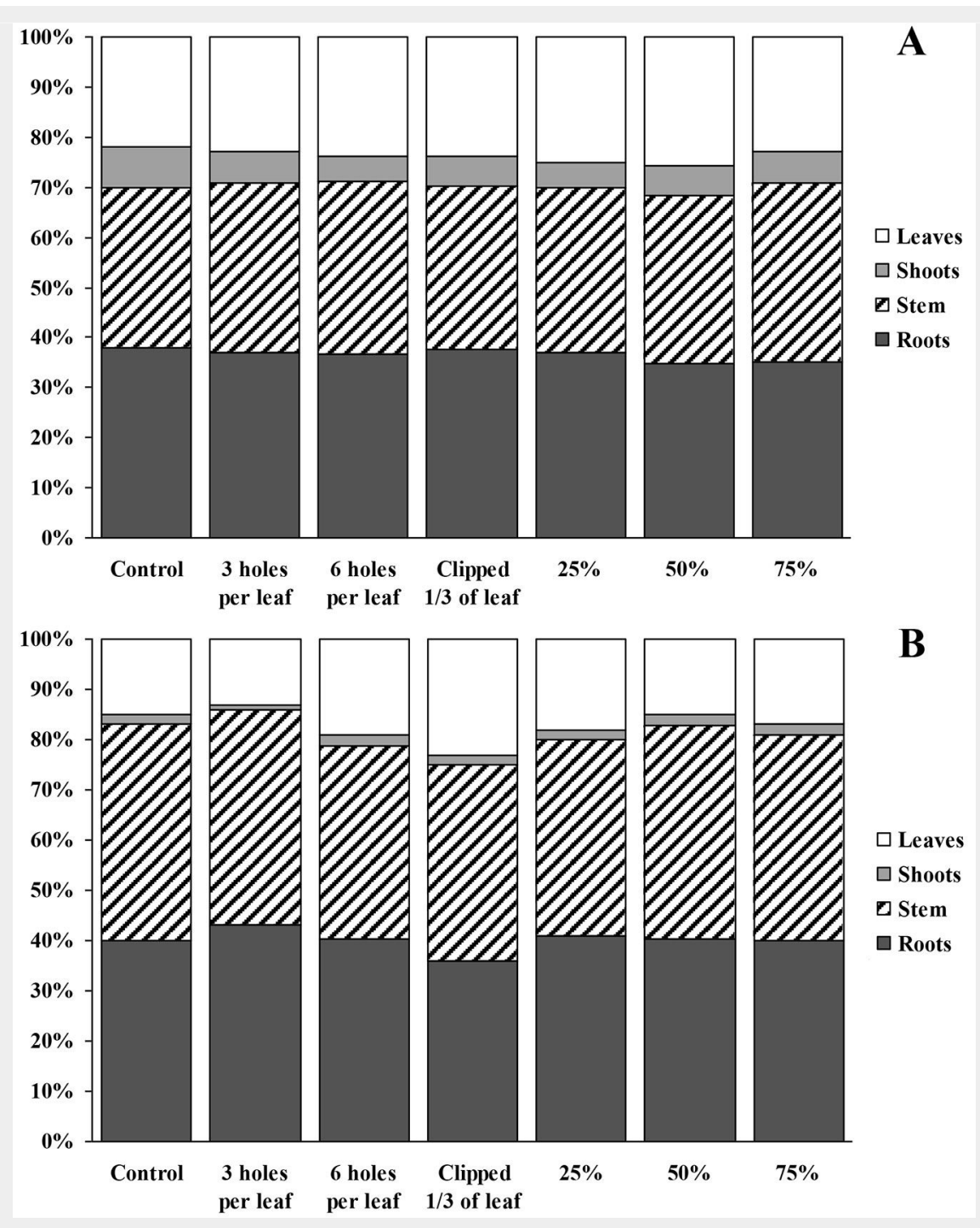

Fig. 6 - Final biomass allocation of fertilized (A) and unfertilized (B) silver birch seedlings at harvest.

and were able to compensate for leaf biomass loss at final harvesting.

Because tree foliage was damaged seedlings lost up to $75 \%$ of leaves - it could be expected that main direct changes were observed in the leaf or aboveground biomass. However, indirect effects could also occur in the roots or even in the total tree biomass. The total leaf mass of unfertilized seedlings that were artificially damaged by perforation with three holes per leaf (or $10 \%$ defoliated) exceeded the leaf mass of the control seedlings by 1.2 times, while leaf production was exceeded by 1.4 times. Seedlings defoliated by $75 \%$ were particularly able to compensate for leaf mass loss, damaged seedlings exceeding the control by 1.5 times (Fig. 4, Fig. 5). In all other cases (all defoliation treatments), growth compensation was also evident: no significant difference from the control indicated positive growth response.

The highest total production of fertilized seedlings was found in the control treatment (Fig. 4). Opposite to unfertilized seedlings, fertilized trees were not able to compensate for leaf mass loss in all cases. Severe defoliation of $50-75 \%$ induced about 1.8-2.0 times lower total production compared to the control. Only weak damage (three holes per leaf, which corresponded to $20 \%$ defoliation; also $25 \%$ defoliation) induced final biomass similar to the control. However, such growth response could be evaluated only as partial compensation. Similar patterns were found in leaf biomass: at final harvest, the leaf production in 50-75\% damaged seedlings remained lower than in the control (Fig. 5).

Biomass growth and allocation to different tree compartments of fertilized and unfertilized silver birch seedlings were quite similar for both damaged and control seedlings (Fig. 6a, Fig. 6b). In the case of applied fertilizers, the biomass was allocated more to stems and roots compared to unfertilized seedlings. The percentage of leaf biomass depended on damage intensity and varied from $13-15 \%$ to $23 \%$. Similarly, a wider range of biomass allocated to stems was recorded in the case of no fertilization.

\section{Discussion}

This study clearly demonstrated that additional nutrient supply is the most important factor for the growth of birch seedlings, both in height and diameter. This is in agreement with most general assertions, which emphasize optimal nutrition as a limiting factor for vegetation. Several previous studies have confirmed the essential role of $\mathrm{N}$ as a key nutrient for growth (Tamm 1991, Ferm et al. 1992, Högberg et al. 2000, Thelin 2000, Nilsen \& Abrahamsen 2003), but the addition of other macronutrients could induce a higher incremental response than $\mathrm{N}$ alone (Ferm et al. 1992, Saarsalmi \& Mälkönen 2001, Ozolinčius et al. 2007). In this study, height and stem diameter of birch seedlings increased by several times as a response to fertilization. Measurement of aboveground biomass and root at harvest also showed very similar trends. Although we found that soil fertilization induced a positive growth response in silver birch seedlings, this cannot be extended to older trees, short-term responses being different to long-term change in tree vitality.

We initially assumed that fertilized trees respond differently to various damage or foliage loss. To this purpose, we applied various defoliation levels (10-75\%) to silver birch seedlings. In addition, 10,20 , and $27 \%$ defoliation was conducted by simulating leaf perforations and clipping part of all leaves per tree, corresponding to three and six holes per leaf and one-third clipped off each leaf, respectively. When the latter leaf damages (leaf holes and clipping) were compared with simple defoliation treatments, when 25,50 , and $75 \%$ of leaves were removed, it was obvious that no significant differences between the two groups of treatments were recorded.

In our study, we determined how lost foliage together with fertilization affects growth compensation in silver birch seedlings. Following Maschinski \& Whitham (1989), Mutikainen et al. (2000), Huttunen et al. (2007) and Eyles et al. (2009), we presumed that defoliated silver birch seedlings grow more intensively and had higher compensation potential when the soil was fertilized. However, our findings did not prove that mineral fertilization up to optimal soil fertility for birch species does compensate the lost foliage at harvest. When the seedlings were fertilized, the increase of both the above- and belowground biomasses showed under compensation compared to the unfertilized control. The seedlings that were artificially defoliated up to $30-40 \%$ did compensate for the lost foliage more intensively than those that had higher defoliation. This non-conformity was very clear when estimating the percentage change of leaf production in comparison with the control (Fig. 5). The reduced compensation was followed by defoliation increase $\left(R^{2}=0.704\right)$; a similar trend was found for root biomass $\left(R^{2}=0.648\right)$.

Nonetheless, the unfertilized birch seed- 
lings under the possible synergetic influence of high defoliation and nutrient limitation showed relatively good growth potential. Indeed, the severe $50-75 \%$ defoliation resulted in higher photosynthesis, and the seedlings grown without additional fertilization showed higher compensation potential. In particular, this effect was significant for higher damage levels. However, we did not measure the impact of repeated damage during the next vegetation periods, which could cause quite different growth variations, especially if seedlings had severe damage during the previous growth season.

These patterns indicate that seedlings of fast growing tree species, such as silver birch, have relatively high potential to respond to various environmental disturbances. However, even in the case of severe damage, additional fertilization does not necessarily lead to more intensive growth. Mineral fertilization up to optimal nutritional balance could be a beneficial tool causing more intensive growth, higher biomass during the vegetation season, short-term response and partial compensation for lost foliage in the case of insect outbreak.

\section{Conclusions}

The mineral fertilizers applied for the 25 $75 \%$-defoliated silver birch seedlings reduced the growth of aboveground biomass compared with the fertilized but undamaged seedlings. Our results showed that when seedlings received more nutrients they did not compensate for the loss of foliar mass. Meanwhile, the seedlings that lost a part of their foliar mass but received no additional fertilizers, compensated for the lost foliage and have not weakened the root growth, using soil nutrients more effectively.

\section{References}

Anttonen S, Piispanen R, Ovaska J, Mutikainen P, Saranpää P, Vapaavuori E (2002). Effects of defoliation on growth, biomass allocation, and wood properties of Betula pendula clones grown at different nutrient levels. Canadian Journal of Forest Research 32: 498-508. - doi: 10.1139/x01-217

Boege K (2005). Influence of plant ontogeny on compensation to leaf damage. American Journal of Botany 92 (10): 1632-1640. - doi: 10.3732/ ajb.92.10.1632

Bonan GB, Shugart HH (1989). Environmental factors and ecological processes in boreal forests. Annual Reviews in Ecology and Systematics 20: 1-28. - doi: 10.1146/annurev.es.20.110189. 000245

Brække FH, Håland B (1995). Above ground biomass and mineral element distribution in Scots pine stand of a virgin low-shrub pine bog. Communications of Skogforsk 47 (7): 17.

Broadmeadow MSJ, Jackson SB (2000). Growth responses of Quercus petraea, Fraxinus excelsior and Pinus sylvestris to elevated carbon dioxide, ozone and water supply. New Phytologist 146: 437-451. - doi: 10.1046/j.1469-8137. 2000.00665.x

Dobbertin M (2005). Tree growth as indicator of tree vitality and of tree reaction to environmental stress: a review. European Journal of Forest Research 124: 319-333. - doi: 10.1007/s10 342-005-0085-3

Erbilgin N, Galvez DA, Zhang B, Najaret A (2014). Resource availability and repeated defoliation mediate compensatory growth in trembling aspen (Populus tremuloides) seedlings. PeerJ 2: e491. - doi: 10.7717/peerj.491

Eyles A, Pinkard EA, Mohammed C (2009). Shifts in biomass and resource allocation patterns following defoliation in Eucalyptus globulus growing with varying water and nutrient supplies. Tree Physiology 29: 753-764. - doi: 10.1093/tree phys/tppo14

Ferm A, Hokkanen T, Moilanen M, Issakainen J (1992). Effects of wood bark ash on the growth and nutrition of Scots pine afforestation in central Finland. Plant and Soil 147: 305-316. - doi: 10.1007/BFoo029082

Finér L (1992). Nutrient concentrations in Pinus sylvestris on an ombrotrophic pine bog, and the effect of PK and NPK fertilization. Scandinavian Journal of Forest Research 7: 205-218. - doi: 10.1080/02827589209382713

Galloway JN, Dentener FJ, Capone DG, Boyer EW, Howarth RW, Seitzinger SP, Asner GP, Cleveland CC, Green PA, Holland EA, Karl DM, Michaels AF, Porter JH, Townsend AR, Vöosmarty CJ (2004). Nitrogen cycles: past, present, and future. Biogeochemistry 70: 153-226. - doi: 10.1007/s10533-004-0370-0

Hawkes CV, Sullivan JJ (2001). The impact of herbivory on plants in different resource conditions: a meta-analysis. Ecology 82: 2045-2058. doi: 10.1890/0012-9658(2001)082[2045:TIOHO P]2.0.CO;2

Högberg $P$, Bengtsson $G$, Berggren $D$, Högberg M, Nilsson I, Nohrstedt H, Persson T, Sjöberg M (2000). How are the nitrogen dynamics of forest soils affected? In: "Effects of Nitrogen Deposition on Forest Ecosystems" (Bertills U, Näsholm T eds). Report no. 5067, Swedish Environmental Protection Agency, Berlings Skogs, Trelleborg, Sweden, pp. 29-53.

Houle G, Simard G (1996). Additive effects of genotype, nutrient availability and type of tissue damage on the compensatory response of Salix planifolia ssp. planifolia to simulated herbivory. Oecologia 107: 373-378. - doi: 10.1007/BF 00328454

Huttunen L, Ayres MP, Niemelä P, Heiska S, Tegelberg R, Rousi M, Kellomäki S (2013). Interactive effects of defoliation and climate change on compensatory growth of silver birch seedlings. Silva Fennica 47 (3), article id 964, pp. 14. doi: $10.14214 /$ sf.964

Huttunen L, Niemelä P, Ossipov V, Rousi M, Klemola T (2012). Do warmer growing seasons ameliorate the recovery of mountain birches after winter moth outbreak? Trees - Structure and Function 26: 809-819. - doi: 10.1007/s00468011-0652-9

Huttunen L, Niemelä P, Peltola H, Heiska S, Rousi M, Kellomäki S (2007). Is a defoliated silver birch seedling able to overcompensate the growth under changing climate? Environmental and Experimental Botany 60: 227-238. - doi: 10.1016/j.envexpbot.2006.10.010
Hytönen J, Saramäki J, Niemistö P (2014). Growth, stem quality and nutritional status of Betula pendula and Betula pubescens in pure stands and mixtures. Scandinavian Journal of Forest Research 29 (1): 1-11. - doi: 10.1080/0282 7581.2013 .838300

Jacquet JS, BosC A, O'Grady A, Jactel H (2014). Combined effects of defoliation and water stress on pine growth and non-structural carbohydrates. Tree Physiology 34: 367-376. - doi: 10.1093/treephys/tpu018

Kula E, Pešlová A, Martinek P (2012). Effects of nitrogen on growth properties and phenology of silver birch (Betula pendula Roth). Journal of Forest Science 58: 391-399. [online] URL: http:// agriculturejournals.cz/publicFiles/75916.pdf

Mäkipää R, Karjalainen T, Pussinen A, Kellomäki $S$ (1999). Effects of climate change and nitrogen deposition on the carbon sequestration of a forest ecosystem in the boreal zone. Canadian Journal of Forest Research 29: 1490-1501. doi: $10.1139 / \times 99-123$

Maschinski J, Whitham TG (1989). The continuum of plant-responses to herbivory - the influence of plant-association, nutrient availability, and timing. The American Naturalist 134: 1-19. doi: $10.1086 / 284962$

Massad TJ (2013). Ontogenetic differences of herbivory on wood and herbaceous plants: a meta-analysis demonstrating unique effects of herbivory on the young and the old, the slow and the fast. Oecologia 172: 1-10. - doi: 10.1007/ soo $442-012-2470-1$

Meier ES, Lischke H, Schmatz DR, Zimmermann NE (2012). Climate, competition and connectivity affect future migration and ranges of European trees. Global Ecology and Biogeography 21: 164-178. - doi: 10.1111/j.1466-8238.2011.006 69.x

Mutikainen $P$, Walls $M$, Ovaska J, Keinänen $M$, Julkunen-Tiitto R, Vapaavuori E (2000). Herbivore resistance in Betula pendula: effect of fertilization, defoliation, and plant genotype. Ecology 81: 49-65. - doi: 10.1890/0012-9658(2000) 081[0049:HRIBPE]2.0.CO;2

Niinemets $U$ (2010). Responses of forest trees to single and multiple environmental stresses from seedlings to mature plants: past stress history, tolerance and acclimation. Forest Ecology and Management 260: 1623-1639. - doi: 10.1016/j.foreco.2010.07.054

Nilsen P, Abrahamsen G (2003). Scots pine and Norway spruce stands responses to annual N, P and $\mathrm{Mg}$ fertilization. Forest Ecology and Management 174: 221-232. - doi: 10.1016/S0378-1127 (02)00024-5

Ozolinčius R, Varnagiryte-Kabašinskiene I, Stakenas V, Mikšys V (2007). Effects of wood ash and nitrogen fertilization on Scots pine crown biomass. Biomass and Bioenergy 31: 700-709. - doi: 10.1016/j.biombioe.2007.06.016

Pinkard EA, Battaglia M, Mohammed CL (2007). Defoliation and nitrogen effects on photosynthesis and growth of Eucalyptus globulus. Tree Physiology 27: 1053-1063. - doi: 10.1093/tree phys/27.7.1053

Pinkard EA, Battaglia M, Roxburgh S, O'Grady AP (2011). Estimating forest net primary production under changing climate: adding pests into the equation. Tree Physiology 31: 686-699. doi: 10.1093/treephys/tpro54 
Reich PB, Walters MB, Krause SC, Vanderklein DW, Raffa KF, Tabone T (1993). Growth, nutrition and gas exchange of Pinus resinosa following artificial defoliation. Trees 7: 67-77. - doi: 10.1007/BF00225472

Saarsalmi A, Mälkönen E (2001). Forest fertilization research in Finland: a literature review. Scandinavian Journal of Forest Research 16: 514-535. - doi: 10.1080/02827580152699358

Stevens MT, Kruger EL, Lindroth RL (2008). Variation in tolerance to herbivory is mediated by differences in biomass allocation in aspen. Functional Ecology 22: 40-47. - doi: 10.1111/j. 1365-2435.2007.01356.x

Tamm CO (1991). Nitrogen in terrestrial ecosystems. Ecology Studies 81, Springer-Verlag, Berlin, Germany, pp. 115.

Thelin G (2000). Nutrient imbalance in Norway spruce. PhD thesis, Lund University, Sweden, pp. 44.

Turnbull TL, Adams MA, Warren CR (2007).
Increased photosynthesis following partial defoliation of field-grown Eucalyptus globulus seedlings is not caused by increased leaf nitrogen. Tree Physiology 27: 1481-1492. - doi: 10.1093/treephys/27.10.1481

Vanhellemont $M$, Van Acker J, Verheyen $K$ (2016). Exploring life growth patterns in birch (Betula pendula), Scandinavian Journal of Forest Research. - doi: 10.1080/02827581.2016.114 1978

Varnagiryte-Kabašinskiene I, Araminiene V, Stakenas V (2015). Effects of artificial defoliation and insect damage on the growth of Betula pendula saplings. iForest - Biogeosciences and Forestry 9: 95-100. - doi: 10.3832/ifor1522-008 Vasechko Gl (1983). An ecological approach to forest protection. Forest Ecology and Management 5: 133-168. - doi: 10.1016/0378-1127(83)900 63-4

Verburg PSJ (2005). Soil solution and extractable soil nitrogen response to climate change in two boreal forest ecosystems. Biology and Fertility of Soils 41: 257-261. - doi: 10.1007/s00374-0050831-1

Waring RH, Savage T, Cromack K, Rose C (1992). Thinning and nitrogen-fertilization in a grand fir stand infested with western spruce budworm. 4. An ecosystem management perspective. Forest Science 38: 275-286. [online] URL: http:// www.ingentaconnect.com/content/saf/fs/1992/ 00000038/00000002/art00007

Wise MJ, Abrahamson WG (2005). Beyond the compensatory continuum: environmental resource levels and plant tolerance of herbivory. Oikos 109: 417-428. - doi: 10.1111/j.0030-1299.20 05.13878.x

Zhang S, Dang QL, Yü X (2006). Nutrient and $\mathrm{CO}_{2}$ elevation had synergistic effects on biomass production but not on biomass allocation of white birch seedlings. Forest Ecology and Management 234: 238-244. - doi: 10.1016/j.foreco.20 06.07 .017 